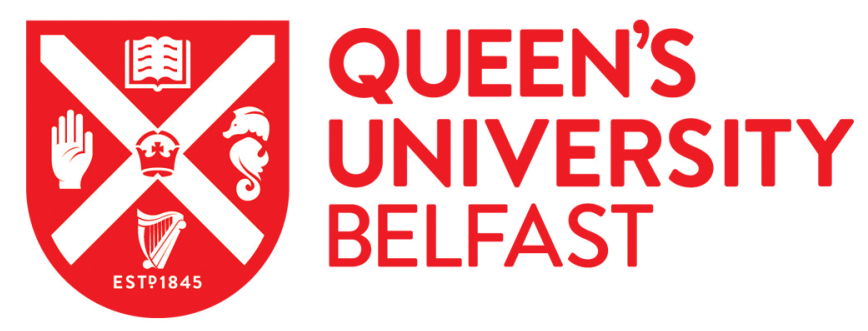

\title{
Waste plastics recycling for producing high-value carbon nanotubes: Investigation of the influence of Manganese content in Fe-based catalysts
}

He, S., Xu, Y., Zhang, Y., Bell, S., \& Wu, C. (2020). Waste plastics recycling for producing high-value carbon nanotubes: Investigation of the influence of Manganese content in Fe-based catalysts. Journal of Hazardous Materials, 402, 123726. https://doi.org/10.1016/j.jhazmat.2020.123726

Published in:

Journal of Hazardous Materials

Document Version:

Peer reviewed version

Queen's University Belfast - Research Portal:

Link to publication record in Queen's University Belfast Research Portal

\author{
Publisher rights \\ () 2020 Elsevier B.V. All rights reserved. \\ This manuscript is distributed under a Creative Commons Attribution-NonCommercial-NoDerivs License \\ (https://creativecommons.org/licenses/by-nc-nd/4.0/), which permits distribution and reproduction for non-commercial purposes, provided the \\ author and source are cited.
}

\section{General rights}

Copyright for the publications made accessible via the Queen's University Belfast Research Portal is retained by the author(s) and / or other copyright owners and it is a condition of accessing these publications that users recognise and abide by the legal requirements associated with these rights.

\section{Take down policy}

The Research Portal is Queen's institutional repository that provides access to Queen's research output. Every effort has been made to ensure that content in the Research Portal does not infringe any person's rights, or applicable UK laws. If you discover content in the Research Portal that you believe breaches copyright or violates any law, please contact openaccess@qub.ac.uk. 


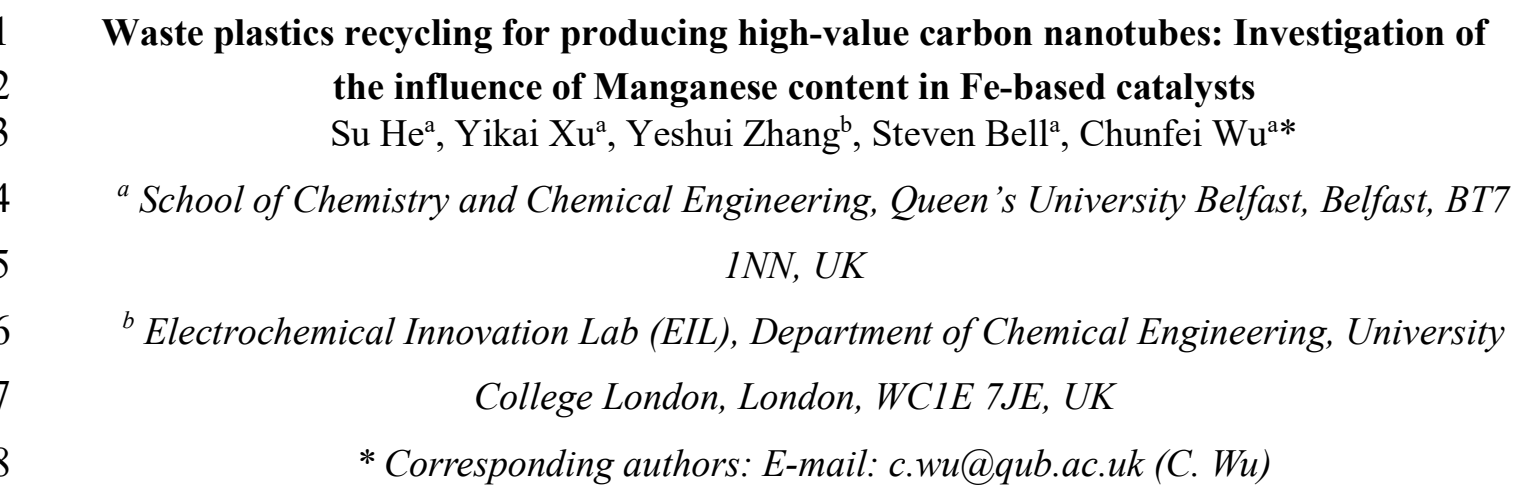

${ }^{a}$ School of Chemistry and Chemical Engineering, Queen's University Belfast, Belfast, BT7

${ }^{b}$ Electrochemical Innovation Lab (EIL), Department of Chemical Engineering, University College London, London, WC1E 7JE, UK

*Corresponding authors: E-mail: c.wu@qub.ac.uk(C.Wu)

Abstract

10 Thermo-chemical conversion is a promising technology for the recycle of waste plastics, as it 11 can produce high-value products such as carbon nanotubes (CNTs) and hydrogen. However, 12 the low yield of CNTs is one of the challenges. In this work, the addition of Mn (0 wt.\%, 1 13 wt. $\%, 5$ wt.\%, and 10 wt.\%) to Fe-based catalyst to improve the production of CNTs has been 14 investigated. Results show that the increase of Mn content from $0 \mathrm{wt} . \%$ to $10 \mathrm{wt} . \%$ significantly 15 promotes CNTs yield formed on the catalyst from $23.4 \mathrm{wt} . \%$ to $32.9 \mathrm{wt} . \%$. The results show 16 that Fe-particles in the fresh catalysts are between 10-25 $\mathrm{nm}$. And the addition of $\mathrm{Mn}$ in the Fe17 based catalyst enhanced the metal-support interactions and the dispersion of metal particles, 18 thus leading to the improved catalytic performance in relation to filamentous carbon growth. In 19 addition, the graphitization of CNTs is promoted with the increase of Mn content. Overall, in 20 terms of the quantity and quality of the produced CNTs, 5 wt.\% of Mn in Fe-based catalyst 21 shows the best catalytic performance, due to the further increase of Mn content from $5 \mathrm{wt} . \%$ to $2210 \mathrm{wt} . \%$ led to a dramatic decrease of purity by $10 \mathrm{wt} . \%$.

Keywords: Waste plastics; carbon nanotubes; Mn-catalyst; thermo-chemical processing; 
Nowdays, plastics are used in various aspects, from household goods such as packaging, clothing, electrical devices, to industrial applications such as automotive parts and insulations (Lettieri and Al-Salem, 2011). The vast demand for plastic results in increasing plastic production year by year. In 2016, plastic production reached 330 million tons and will double within the next 20 years under the current estimationed growth rate (Lebreton and Andrady, 2019). The extensive use of plastics generates a large amunt of wastes. These waste plastics cause severe environmental pollution if they were not well managed. The general methods for plastics waste management include landfill, energy recovery and recycling. Landfill is the most common method for plastic waste treatment in developing countries due to the cheap cost. Even in Europe, $\sim 31 \%$ of waste plastics still goes to land fill, wasting energy stored in the plastic and also causing severe environmental challenges (Drzyzga and Prieto, 2019; Lebreton and Andrady, 2019). In pricinple, recycling of plastic waste provides a more economical and environmental-friendly solution. However, current state of the art technologies of plastic wastes recycling mostly produce low-value products, such as cricks and road construction materials. Therefore, converting waste plastics into high-value products such as carbon nanotubes (CNTs) is a promising alternative for plastic waste management.

Since its discovery by Iijima in 1991 (Iijima, 1991), the extraordinary mechanical and electrical properties of CNTs have allowed it to find a variety of potential applications, such as drug delivery (Bianco et al., 2005), energy storage (Landi et al., 2009), materials strengthening (Andrews et al., 2002), etc. As a result, CNTs production from catalytic pyrolysis of plastic waste has been obtaining increasing interest. The key component to plastic pyrolysis is the catalyst which determins both the yield and quality of the produced CNTs.

In the chemical vapour deposition (CVD) synthesis of CNTs from various carbon feedstocks, $\mathrm{Fe}, \mathrm{Co}$ and Ni are the most effective and widely used catalysts (Shah and Tali, 2016). The using of different catalysts could lead to the different properties and yield of CNTs. Lee et al. investigated the influence of $\mathrm{Fe}, \mathrm{Co}$ and $\mathrm{Ni}$-silica supported catalysts and reported that $\mathrm{Fe}$ catalyst resulted in the best crystallinity of produced CNTs. Sivakumar et al. reported that the produced CNTs over Ni catalyst have higher thermal stability than Fe catalyst (Sivakumar et al., 2011). In addition, the morphology and quality of the produced CNTs were also strongly affected by carbon feedstocks (Yan et al., 2015). In the catalytic synthesis of CNTs using plastic as carbon source, extensive researches have also been conducted on a range of metals e.g. Fe (Wu et al., 2017a), Ni (Yao et al., 2018) and Co (Acomb et al., 2016). Acomb et al. produced

60 CNTs using $\mathrm{Fe} / \mathrm{Al}_{2} \mathrm{O}_{3}$ catalyst from catalytic pyrolysis of LDPE (Low-Density Polyethylene) 61 and obtained carbon deposition yielded $26 \mathrm{wt}$ \% (Acomb et al., 2016). Yao et al. reported using $\mathrm{Fe} / \alpha-\mathrm{Al}_{2} \mathrm{O}_{3}$ and $\mathrm{Fe} / \gamma-\mathrm{Al}_{2} \mathrm{O}_{3}$ catalyst to produce CNTs from real world plastics, and the carbon yielded 35.2 and $32.6 \mathrm{wt} . \%$, respectively (Yao et al., 2018). In Wu et al's work, $\mathrm{Fe} / \mathrm{SiO}_{2}$ catalysts were used to produce CNTs with carbon yield 29 wt.\% from PP(Wu et al., 2017a). In the previous work, compared to Ni or Co based catalyst, Fe-based catalysts lead to a higher yield of carbon from catalytic conversion of plastics, which is owing to the higher carbon solubility and higher carbon diffusion rate of iron nanoparticles (Deck and Vecchio, 2006) as well as the appropriate strength of metal-support interactions (Acomb et al., 2016).

69 Mn acting as an effective promoter was used in a variety catalytic reactions, such as the 
Fischer-Tropsch process (Bezemer et al., 2006; Ding et al., 2013; Xu et al., 2013a; Zhao et al., 2012), volatile organic compounds oxidation (Tang et al., 2014), and the decomposition of nitrous oxides (Jia et al., 2016; Karásková et al., 2010). As for the synthesis of CNTs, Mn as a promoter in Ni-based and Co-based catalysts have also been reported from various carbon feedstocks (Zein and Mohamed, 2004)(Nahil et al., 2015)(Wu et al., 2017b). The promoting effects of Mn in Ni-based catalyst for CNTs synthesis from methane were reported by several researchers. For example, Zein et. al reported $\mathrm{Mn}-\mathrm{Ni} / \mathrm{TiO}_{2}$ catalysts prepared by three different methods for the production of hydrogen and CNTs from methane (Zein and Mohamed, 2004). However, only a fixed content of Mn (15 wt.\%) was used in the research, and the reasons for the catalytic performance was not clear. Ran et. al further investigated the doping effect of $\mathrm{Mn}$ on CNTs formation in the presence of $\mathrm{Ni} / \mathrm{MgO}$ catalysts with varied $\mathrm{Mn}$ content. It was found that the addition of $\mathrm{Mn}$ to the $\mathrm{Ni} / \mathrm{MgO}$ catalyst significantly increased the carbon yield, with the highest carbon yield produced by the catalyst with Mn:Ni a molar ratio of 0.2:1 (Ran et al., 2014). In addition, Becker et al. reported that Mn-Co catalysts with Mn:Co molar ratio of 1:1 led to the highest CNTs yield using ethene as carbon source (Becker et al., 2011). He et. al applied $\mathrm{Mn}-\mathrm{Fe} / \mathrm{MgO}$ catalyst to improve the chirality distribution of the produced single-walled CNTs using CO as carbon source (He et al., 2016).

Mn's promoting effects have also been investigated in the CNTs synthesis from waste plastics. In Nahil et. al's work, a variety of metals ( $\mathrm{Zn}, \mathrm{Mg}, \mathrm{Ca}, \mathrm{Ce}, \mathrm{Mo}, \mathrm{Mn}$, etc.) added into Ni-based catalysts have been investigated for the catalytic conversion of waste plastics (polypropylene) into CNTs (Nahil et al., 2015). It was found that the addition of Mn into Nibased catalyst resulted in the highest yield of CNTs. Further work by Wu et al. investigated the effects of Mn content on CNTs synthesis in the Ni-based catalyst. The Mn-Ni/ $\mathrm{Al}_{2} \mathrm{O}_{3}$ catalyst with $\mathrm{Mn}: \mathrm{Ni}$ a molar ratio of 2:2 produced a higher yield of carbon compared to $\mathrm{Mn}: \mathrm{Ni}$ with a molar ratio of 2:1 in the synthesis of CNTs using waste plastics (polypropylene) as carbon feedstock.

Owing to the great catalytic performance of Fe-based catalyst and $\mathrm{Mn}$ as a promising promoter in CNTs formation from plastics, there is a potential of further increasing CNTs production and quality by doping $\mathrm{Mn}$ into Fe-based catalyst during catalytic conversion of waste plastics. Therefore, in this work, we report the influence of Mn content in the Fe-based catalyst for CNTs production from catalytic pyrolysis of waste plastics. This work aims to optimise the development of Fe-based catalysts by adding Mn in relation to CNTs production from waste plastics.

\section{Experimental}

\subsection{Materials and preparation of catalyst}

The plastic raw material used in this study was recycled polypropylene (PP) pellet obtained from regain polymer Ltd. with a diameter of $\sim 2 \mathrm{~mm}$. The chemicals $\mathrm{Mn}\left(\mathrm{NO}_{3}\right)_{2} \bullet \mathrm{H}_{2} \mathrm{O}\left(98 \%\right.$, Sigma-Aldrich, cat. no. 288640) and $\mathrm{Fe}\left(\mathrm{NO}_{3}\right)_{3} \bullet 9 \mathrm{H}_{2} \mathrm{O}(\geq 98 \%$, ACS reagent, Sigma-Aldrich, cat. no. 16828) were used as starting materials. $\mathrm{Al}_{2} \mathrm{O}_{3}$ ( $\geq 98 \%$, puriss, Sigma-Aldrich, cat. no. 11028) with particle size around $10 \mu \mathrm{m}$ is used as the catalyst support. All materials were used directly without any pre-treatment. $\mathrm{MnFe} / \mathrm{Al}_{2} \mathrm{O}_{3}$ catalysts were prepared by a wet impregnation method. The catalysts 
contain 10 wt. $\%$ of Fe. The content of $\mathrm{Mn}$ is 0 wt. $\%, 1$ wt. $\%, 5$ wt. $\%$ and 10 wt. $\%$, respectively. And the corresponding catalyst is assigned as $0 \mathrm{Mn} 10 \mathrm{Fe}, 1 \mathrm{Mn} 10 \mathrm{Fe}$, $5 \mathrm{Mn} 10 \mathrm{Fe}$ and $10 \mathrm{Mn} 10 \mathrm{Fe}$, respectively. For comparison, a catalyst with $10 \mathrm{wt} . \% \mathrm{Mn}$ without $\mathrm{Fe}(10 \mathrm{Mn} 0 \mathrm{Fe})$ was prepared use the same method.

116 During catalyst preparation, the required amount of $\mathrm{Mn}\left(\mathrm{NO}_{3}\right)_{2} \bullet \mathrm{xH}_{2} \mathrm{O}$ and $\mathrm{Fe}\left(\mathrm{NO}_{3}\right)_{3} \bullet 9 \mathrm{H}_{2} \mathrm{O}$ 117 were dissolved in $100 \mathrm{ml}$ of deionized water, and the mixture solution was stirred for $\sim 0.5 \mathrm{~h}$ 118 until the chemicals were fully dissolved. The required amount of $\mathrm{Al}_{2} \mathrm{O}_{3}$ was then slowly added 119 into the mixture solution and stirred for $\sim 1 \mathrm{~h}$. After that, water was removed by evaporation at $12090{ }^{\circ} \mathrm{C}$, followed by drying in an oven at $105{ }^{\circ} \mathrm{C}$ overnight to remove the remaining water. 121 Finally, the dried catalyst precursors were grounded into a fine powder and then were heated 122 in the air atmosphere at a heating rate of $10^{\circ} \mathrm{C} \mathrm{min}^{-1}$ to $500{ }^{\circ} \mathrm{C}$ for $3 \mathrm{~h}$ of calcination.

\subsection{Catalytic pyrolysis of plastic waste into CNTs}

The catalytic pyrolysis of plastic waste into CNTs was performed in a two-stage reactor in this study. Fig. 1 shows the schematic diagram of this reaction system. The first-stage reactor consists of a horizontal quartz tube placed in a tubular furnace for PP pyrolysis. The generated vapor was carried by $\mathrm{N}_{2}$ with a flow rate of $100 \mathrm{ml} \mathrm{min}^{-1}$ and after condensation, the noncondensed products passed through the second-stage of the reactor.

For each run of the experiment, $2 \mathrm{~g}$ of PP was located inside an aluminium boat in the centre of the first-stage reactor, and $0.5 \mathrm{~g}$ of catalyst supported by $\sim 30 \mathrm{mg}$ of quartz wool was located in the centre of the second-stage reactor. The reaction system was purged by $\mathrm{N}_{2}$ for $\sim 10 \mathrm{~min}$ before the second-stage reactor started to heat from room temperature to $800^{\circ} \mathrm{C}$ with a heating rate of $40{ }^{\circ} \mathrm{C} \mathrm{min}^{-1}$. When the second-stage reactor reached the set point temperature, the firststage reactor containing $2 \mathrm{~g}$ of PP started to heat from room temperature to $200{ }^{\circ} \mathrm{C}$ with a heating rate of $40{ }^{\circ} \mathrm{C} \mathrm{min}^{-1}$, followed by heating from $200{ }^{\circ} \mathrm{C}$ to $500{ }^{\circ} \mathrm{C}$ with a heating rate of $10^{\circ} \mathrm{C} \mathrm{min}^{-1}$. After $\sim 1 \mathrm{~h}$ of reaction time, the reaction system was slowly cooled down to room temperature under $\mathrm{N}_{2}$ protection, and the reacted catalyst together with the produced CNTs were collected for further characterisations. The Fe-based catalysts with different Mn contents associated with the production of CNTs were studied.

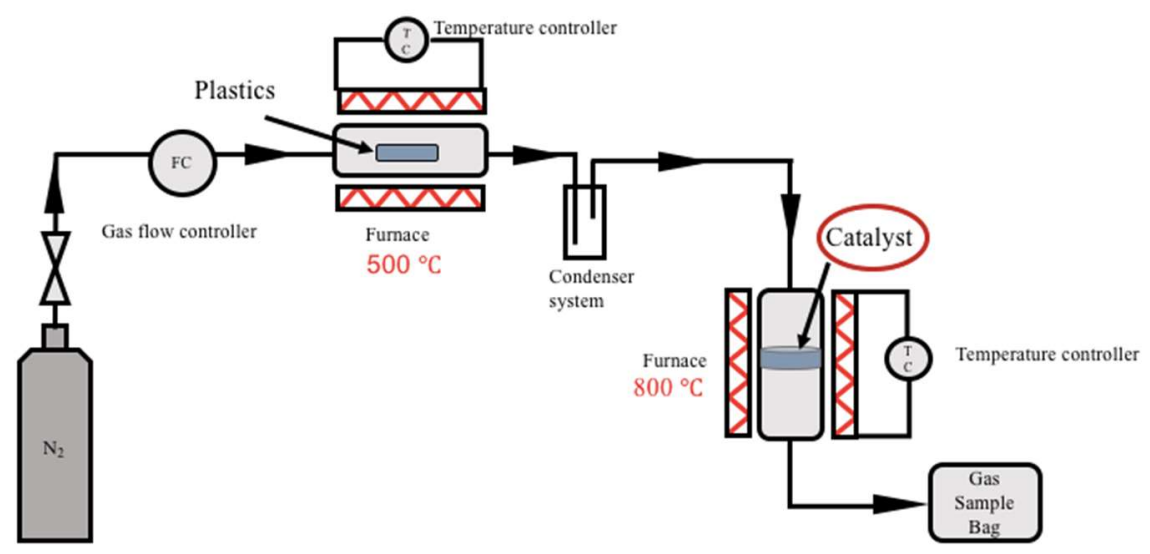

Fig. 1. Schematic diagram of the two-stage reaction system. 
TA Instruments TGA 2950 thermogravimetric analyser (TGA) was used to analyse the temperature programme reduction (TPR) of the fresh catalyst to observe the reduction of the catalyst metal. Under a mixed gas of $\mathrm{H}_{2}$ and $\mathrm{N}_{2}$ gas ( 5 vol.\% : 95 vol.\%), $\sim 50 \mathrm{mg}$ of catalyst was heated from room temperature to $100{ }^{\circ} \mathrm{C}$ at a heating rate of $10{ }^{\circ} \mathrm{C} \mathrm{min}{ }^{-1}$ and held for 10 min, then the temperature increased to $950^{\circ} \mathrm{C}$ under at the same heating rate to record the TPR curve.

149 Temperature programme oxidation (TPO) analysis for the reacted catalysts was conducted by the same TGA 2950 equipment using air gas to measure the amount of carbon formed on the reacted catalyst and to distinguish different types of carbons, such as amorphous carbons or graphite. For each TPO process, $\sim 30 \mathrm{mg}$ of reacted catalyst sample was heated to $800{ }^{\circ} \mathrm{C}$ in air at a heating rate of $15^{\circ} \mathrm{C} \mathrm{min}^{-1}$. The fresh and reacted catalysts were also characterized by a Panalytical X-ray diffraction (XRD) equipment with a scanning step of $0.033^{\circ}$ using $\mathrm{Cu} \bullet \mathrm{k} \alpha 1$ radiation in the range from $5^{\circ}$ to $80^{\circ}$ and the data was analysed with Highscore software. The strongest peak was chosen to calculate the crystallite size by Scherrer equation. The surface morphology and diameter of the metal particles of the catalysts were observed with a FEI Quanta FEG Oxford Ex-ACT scanning electron microscope (SEM) and a Jeol 2100 LaB6 transmission electron microscope (TEM). The WITec Alpha 300R Confocal Raman Microscope equipped with a $532 \mathrm{~nm}$ diode laser with an output power of $30 \mathrm{mWwas}$ used to perform Raman spectroscopic analysis of the reacted catalyst.

\section{Results and discussion}

\subsection{Characterization of fresh catalysts}

XRD results of the prepared Fe-based catalysts with varied Mn contents are shown in Fig. 2. In general, the diffraction patterns of all four catalysts are dominated by the characteristic peaks of $\alpha-\mathrm{Fe}_{2} \mathrm{O}_{3}$ at $4.2^{\circ}, 33.3^{\circ}, 35.7^{\circ}, 41.05^{\circ}, 49.71^{\circ}, 54.36^{\circ}, 62.74^{\circ}, 64.30^{\circ} 2 \theta$, indicating that the main composition of the catalysts are $\alpha-\mathrm{Fe}_{2} \mathrm{O}_{3}$. For the $0 \mathrm{Mn} 10 \mathrm{Fe}$ catalyst, the diffraction patterns only consist of peaks corresponding to $\alpha-\mathrm{Fe}_{2} \mathrm{O}_{3}$ and $\mathrm{Al}_{2} \mathrm{O}_{3}$. For the Mn-doped catalysts, the XRD data show weak diffraction of manganese oxides, which is in good agreement with literatures (Feyzi and Jafari, 2012; Lee et al., 1991; Nasser et al., 2018; Yang et al., 2005). This might be due to $\mathrm{Mn}$ was present as amorphous or highly dispersed on the surface of the $\mathrm{Al}_{2} \mathrm{O}_{3}$ support (Nasser et al., 2018).

The size of the $\alpha-\mathrm{Fe}_{2} \mathrm{O}_{3}$ crystallite phase was calculated using the Scherrer equation. For the $0 \mathrm{Mn} 10 \mathrm{Fe}$ catalyst, the crystallite size is $107.1 \mathrm{~nm}$. Interestingly, it is found that the crystallite size of $1 \mathrm{Mn} 10 \mathrm{Fe}, 5 \mathrm{Mn} 10 \mathrm{Fe}$ and $10 \mathrm{Mn} 10 \mathrm{Fe}$ catalyst are much smaller, at $14.0 \mathrm{~nm}, 8.4 \mathrm{~nm}$, and $30.3 \mathrm{~nm}$, respectively. It is indicated that an appropriate amount of $\mathrm{Mn}$ dopant could significantly improve the dispersion of iron in the catalyst. The crystallite size of the $10 \mathrm{Mn} 10 \mathrm{Fe}$ catalyst is larger than the $5 \mathrm{Mn} 10 \mathrm{Fe}$ catalyst, which could be resulted from the excessive amount of Mn dopant in the catalyst. It is now well-established that the size of the catalyst particles are crucial for CNTs formation and that larger particles often exhibit lower catalytic activities due to the reduced active-surface area (Acomb et al., 2016; Liu et al., 2009). Therefore, the above findings demonstrate that an appropriate amount of $\mathrm{Mn}$ is required to be added to the Fe-based catalyst in terms of the catalytic conversion of waste platics to form CNTs. 


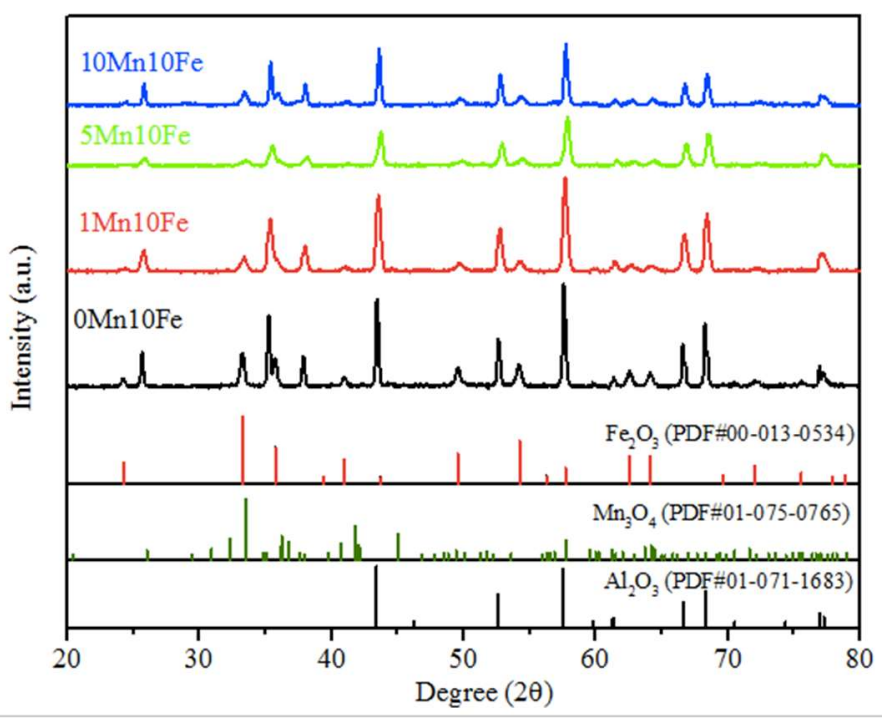

185

Fig. 2. X-ray diffraction of the freshFe-based catalysts with different amount of (Mn $0 \mathrm{Mn} 10 \mathrm{Fe}, 1 \mathrm{MnFe}, 5 \mathrm{Mn} 10 \mathrm{Fe}$ and $10 \mathrm{Mn} 10 \mathrm{Fe})$.

The $\mathrm{H}_{2}$-TPR results for the four catalysts are shown in Fig. 3. Several reduction peaks are obtained since both $\mathrm{Fe}$ and $\mathrm{Mn}$ elements possess several types of oxide forms and the reduction of $\mathrm{Fe}_{2} \mathrm{O}_{3}$ and $\mathrm{Mn}_{3} \mathrm{O}_{4}$ proceed subsequentially. Hydrogen reduction of $\mathrm{Fe}_{2} \mathrm{O}_{3}$ involves two or three steps according to different reduction temperatures (Pineau et al., 2006): when the reduction temperature is below $570{ }^{\circ} \mathrm{C}$, wüstite $\mathrm{FeO}$ was formed as an intermediate product before the formation of $\mathrm{Fe}$, as illustrated in Eq. (1); when the reduction temperature is above $570{ }^{\circ} \mathrm{C}, \mathrm{Fe}_{2} \mathrm{O}_{3}$ reduced into $\mathrm{Fe}_{3} \mathrm{O}_{4}$ and then directly reduced into $\mathrm{Fe}$, as shown in Eq. (2):

$\mathrm{Fe}_{2} \mathrm{O}_{3} \rightarrow \mathrm{Fe}_{3} \mathrm{O}_{4} \rightarrow \mathrm{FeO} \rightarrow \mathrm{Fe}$

$\mathrm{Fe}_{2} \mathrm{O}_{3} \rightarrow \mathrm{Fe}_{3} \mathrm{O}_{4} \rightarrow \mathrm{Fe}$

As indicated in Fig. 3, the $0 \mathrm{Mn} 10 \mathrm{Fe}$ catalyst undergoes two stages of reduction. $\sim 0.68$ wt.\% weight loss occurred in the first stage and $\sim 5.5 \mathrm{wt} . \%$ weight loss occurred in the second stage. The first reduction peak at $420{ }^{\circ} \mathrm{C}$ can be attributed to the reduction of $\alpha-\mathrm{Fe}_{2} \mathrm{O}_{3}$ to $\mathrm{Fe}_{3} \mathrm{O}_{4}$. The second broad peak as illustrated in the range of $450-750{ }^{\circ} \mathrm{C}$ can be attributed to the subsequentially reduction of $\mathrm{Fe}_{3} \mathrm{O}_{4}$ to $\mathrm{FeO}$ and $\mathrm{Fe}$ following Eq.(1) process. $1 \mathrm{Mn} 10 \mathrm{Fe}$ have three reduction stages, which have a weight loss of $0.47 \mathrm{wt} . \%, 0.69 \mathrm{wt} . \%$ and $2.47 \mathrm{wt.} \%$, respectively. $1 \mathrm{Mn} 10 \mathrm{Fe}$ shows a major reduction peak in the first stage for the reduction of $\alpha$ $\mathrm{Fe}_{2} \mathrm{O}_{3}$ to $\mathrm{Fe}_{3} \mathrm{O}_{4}$ which shifted towards higher temperature compared to $0 \mathrm{Mn} 10 \mathrm{Fe}$. Meanwhile, the first stage weight loss for $1 \mathrm{Mn} 10 \mathrm{Fe}$ is lower than that compared to $0 \mathrm{Mn} 10 \mathrm{Fe}$. These suggesting that the Mn-doped catalyst is more resistant to the reduction and the metal-support interactions is enhanced with the addition of $\mathrm{Mn}$. The new peak appearring at $540{ }^{\circ} \mathrm{C}$ for $1 \mathrm{Mn} 10 \mathrm{Fe}$ catalyst indicates that the reduction of $\mathrm{Fe}_{3} \mathrm{O}_{4}$ to $\mathrm{Fe}$ via $\mathrm{FeO}$ is further stabilized by MnO (Leith and Howden, 1988; Yang et al., 2005, 2004).The weight loss of four reduction stages for the $5 \mathrm{Mn} 10 \mathrm{Fe}$ catalyst are $0.58 \mathrm{wt} . \%, 0.61 \mathrm{wt} . \%, 0.92 \mathrm{wt} . \%$ and $2.4 \mathrm{wt} . \%$, respectively. And the $10 \mathrm{Mn} 10 \mathrm{Fe}$ catalyst showes an obvious increase of weight loss in the first two reduction peaks, which are $1.4 \mathrm{wt} . \%$ and $1.3 \mathrm{wt} . \%$. respectively. For the third and fourth reduction stages, 
it shows a similar weight loss value compared to the $1 \mathrm{Mn} 10 \mathrm{Fe}$ and $5 \mathrm{Mn} 10 \mathrm{Fe}$ catalysts. The new reduction peak appears at $\sim 370{ }^{\circ} \mathrm{C}$ for the $5 \mathrm{Mn} 10 \mathrm{Fe}$ and $10 \mathrm{Mn} 10 \mathrm{Fe}$ catalysts can be attirbuted to the large amount of $\mathrm{Mn}_{3} \mathrm{O}_{4}$ which is reduced into $\mathrm{Mn}$ with $\mathrm{MnO}$ as intermediates. This indicates the overall weight loss is increased from $3.63 \mathrm{wt} . \%$ to $6.1 \mathrm{wt} . \%$ when the $\mathrm{Mn}$ content increases from $1 \mathrm{wt} . \%$ to $10 \mathrm{wt} . \%$ in the catalyst, but the corresponding reduction weight loss for $\mathrm{Fe}_{3} \mathrm{O}_{4}$ is similar. In addition, the major $\alpha-\mathrm{Fe}_{2} \mathrm{O}_{3}$ reduction peak for the $5 \mathrm{Mn} 10 \mathrm{Fe}$ and $10 \mathrm{Mn} 10 \mathrm{Fe}$ catalysts shifts towards higher temperature at $\sim 430{ }^{\circ} \mathrm{C}$ compared to the $1 \mathrm{Mn} 10 \mathrm{Fe}$ catalyst, suggesting that increasing the Mn loading from $0-5 \mathrm{wt} \%$ improves the metal-support interactions but the further increase of Mn loading to $10 \mathrm{wt} . \%$ has slight impacts on the metal-support interaction.

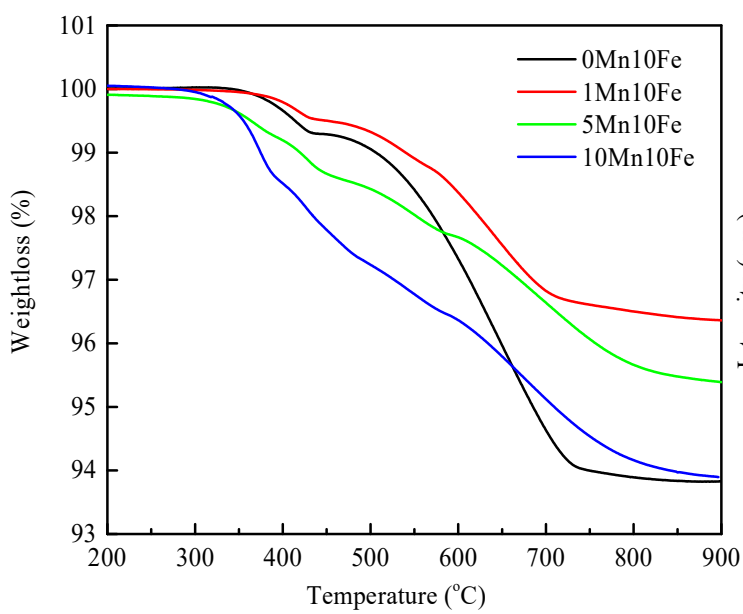

(a)

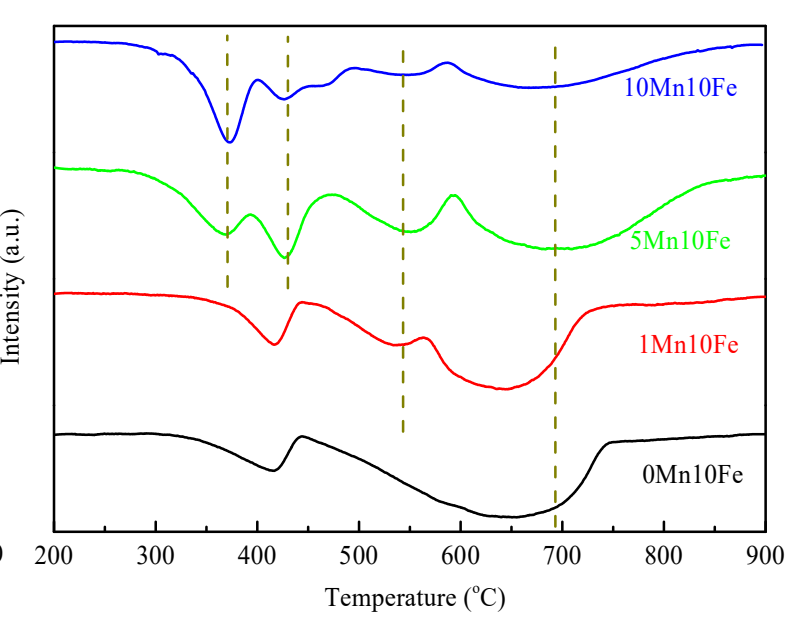

(b)

Fig. 3. TPR (a) and DTG-TPR (b) profiles of the fresh Fe-based catalysts with varied amount of $\mathrm{Mn}$ in the catalysts $(0 \mathrm{Mn} 10 \mathrm{Fe}, 1 \mathrm{MnFe}, 5 \mathrm{Mn} 10 \mathrm{Fe}$ and $10 \mathrm{Mn} 10 \mathrm{Fe})$.

\subsection{The production of CNTs}

\subsubsection{Temperature programmed oxidation (TPO) of the reacted catalysts}

TPO results of the reacted catalysts $(0 \mathrm{Mn} 10 \mathrm{Fe}, 1 \mathrm{MnFe}, 5 \mathrm{Mn} 10 \mathrm{Fe}$ and $10 \mathrm{Mn} 10 \mathrm{Fe})$ are shown in Fig.4. Based on previous work, the weight loss of amorphous carbons and filamentous carbons can be distinguished using oxidation temperature due to their different oxidation properties: the weight loss occurred before $600{ }^{\circ} \mathrm{C}$ corresponds to the oxidation of amorphous carbon, while the weight loss occured after $600{ }^{\circ} \mathrm{C}$ is related to the oxidation of filamentous carbon (assumed as CNTs in this study) (Wu and Williams, 2009; Yang et al., 2015; Zhang et al., 2017). From Fig. 4(a), a slight increase of the catalyst weight between 350 and $500{ }^{\circ} \mathrm{C}$ is observed due to the oxidation of $\mathrm{Mn}$ and $\mathrm{Fe}$. For the reacted $10 \mathrm{Mn} 0 \mathrm{Fe}$ catalyst, no weight loss is observed, which indicates that almost no carbons are deposited on the surface of the reacted catalyst. Therefore, it is demonstrated that the $10 \mathrm{Mn} 0 \mathrm{Fe}$ catalyst without $\mathrm{Fe}$ is inactive for carbon formation. However, the remaining four Fe-based catalysts show a significantly increase of weight loss with increasing Mn content and the $10 \mathrm{Mn} 10 \mathrm{Fe}$ catalyst gives the highest carbon formation ( $\sim 41.5 \mathrm{wt} . \%$ of the total catalyst), as shown in Fig.4(a). It is indicated that Fe is the active sites and Mn promotes the catalytic conversion of waste PP to form carbon. Other 
researchers have obtained similar results, that is, Mn acted as a promoter for the production of CNTs in Ni-based (Ran et al., 2014; Zein and Mohamed, 2004) and Co-based catalysts (Becker et al., 2011).

The yield of amorphous and filamentous carbons are determined by the TGA-TPO curves according to their different oxidation temperatures/thermal stabilities. The carbon yield of amorphous and filamentous carbons for each catalyst is obtained according to Eq.(3). This is calculated based on the weight loss of each reacted catalysts on TGA-TPO results as shown in Fig. 4. And the calculation results are shown in Fig. 5(a).

$$
m_{i}=\frac{w_{i}}{M} \times 100 \%
$$

Where ' $i$ ' means amorphous or filamentous carbons. The ' $w_{i}$ ' represents the weight of amorphous or filamentous carbons deposited on the surface of reacted, ' $M$ ' represents the mass of reacted catalyst, and ' $m_{i}$ ' means the yield of amorphous or filamentous carbons, respectively.

Fig. 4. TGA-TPO (a) and DTG-TPO (b) patterns of reacted catalyst with different amount of

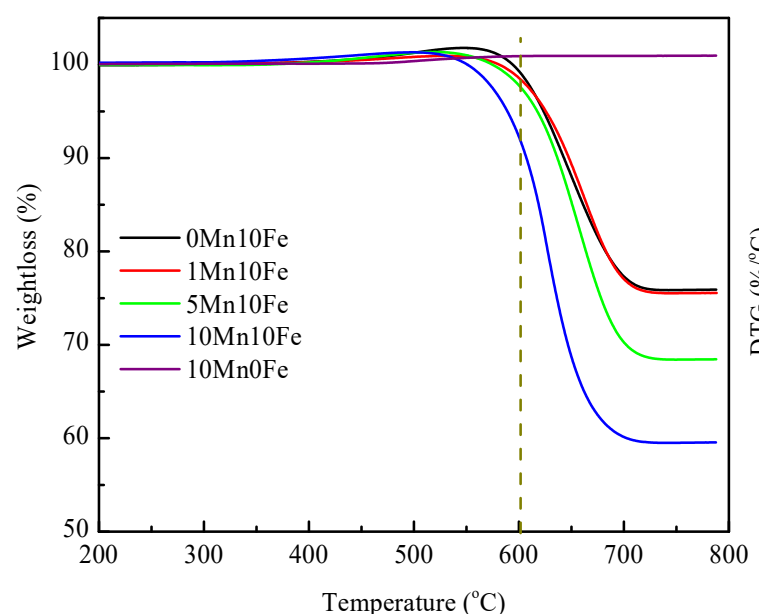

(a

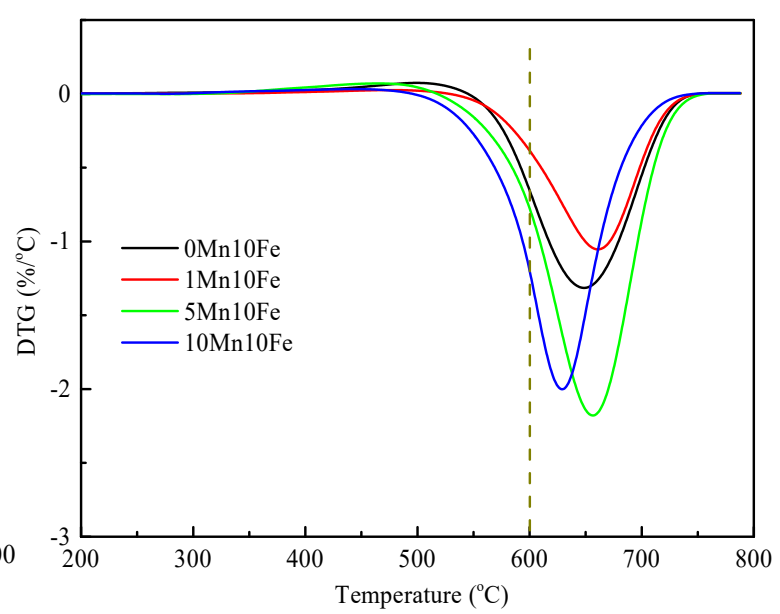

(b

$\mathrm{Mn}$ addition in the catalysts $(0 \mathrm{Mn} 10 \mathrm{Fe}, 1 \mathrm{MnFe}, 5 \mathrm{Mn} 10 \mathrm{Fe}, 10 \mathrm{Mn} 10 \mathrm{Fe}$ and $10 \mathrm{Mn} 0 \mathrm{Fe})$.

As shown in Fig. 5(a), the addition of 1 wt.\% of Mn into Fe-based catalyst shows slight increase on carbon content. A further increase of $\mathrm{Mn}$ to $5 \mathrm{wt} . \%$ and $10 \mathrm{wt} . \%$ results in a significantly incrase of both amorphous and filamentous carbons. It is worth noting that when the $\mathrm{Mn}$ content is increased from $1 \mathrm{wt} . \%$ to $5 \mathrm{wt} . \%$, the yield of filamentous carbons significantly increases by $\sim 6 \mathrm{wt} . \%$. However, as shown in Fig. 5 , when the Mn content is further increased from $5 \mathrm{wt} . \%$ to $10 \mathrm{wt} . \%$, the yield of filamentous carbon is only increased by $\sim 2.5$ wt. $\%$ while amorphous carbon increases by $\sim 5 \mathrm{wt} . \%$.

The mass ratio between amorphous and filamentous carbons for different catalysts is calculated according to Eq.(4) based on the carbon yield calculated from Eq.(3), and the calculation results are shown in Fig. 5(b).

$$
M_{i}(\%)=\frac{m_{i}}{\sum m_{i}} \times 100 \%
$$

269 Where the ' $M_{i}$ ' mean the mass ratio of filamentous and amorphous carbon.

270 As shown in Fig. 5(b), the mass ratios of amorphous and filamentous carbons generated on 271 the $0 \mathrm{Mn} 10 \mathrm{Fe}, 1 \mathrm{Mn} 10 \mathrm{Fe}$ and $5 \mathrm{Mn} 10 \mathrm{Fe}$ catalysts are similar. However, when the Mn content 
reaches $10 \mathrm{wt} . \%$, the mass ratio of unwanted amorphous carbons is significantly increased to $20.9 \mathrm{wt} . \%$. Although increasing the addition of Mn from 0-10 wt.\% promotes carbon formation for both filamentous and armophous carbons as shown in Fig. 5(a), to some extent, the influence of $\mathrm{Mn}$ addition on the mass ratio of filamentous and armophous carbons is different. The addition of $\mathrm{Mn}$ in the range of $0-5 \mathrm{wt} . \%$ shows less influence on the mass ratio of produced filamentous carbons while a further addition of $\mathrm{Mn}$ to $10 \mathrm{wt} . \%$ dramastically reduces the mass ratio of filamentous carbons. It is suggested that the addition of $\mathrm{Mn}$ in the range of $0-5 \mathrm{wt} . \%$ promotes CNTs growth and the further increase of Mn content favours the formation of amorphous carbons. In addition, the DTG-TPO results in Fig.4(b) show that the oxidation peak for the $10 \mathrm{Mn} 10 \mathrm{Fe}$ catalyst occures at lower temperature compared to $0 \mathrm{Mn} 10 \mathrm{Fe}, 1 \mathrm{Mn} 10 \mathrm{Fe}$ and $5 \mathrm{Mn} 10 \mathrm{Fe}$. It is indicated that a lower oxidation peak is corresponding to a higher mass ratio of amorphous carbons.

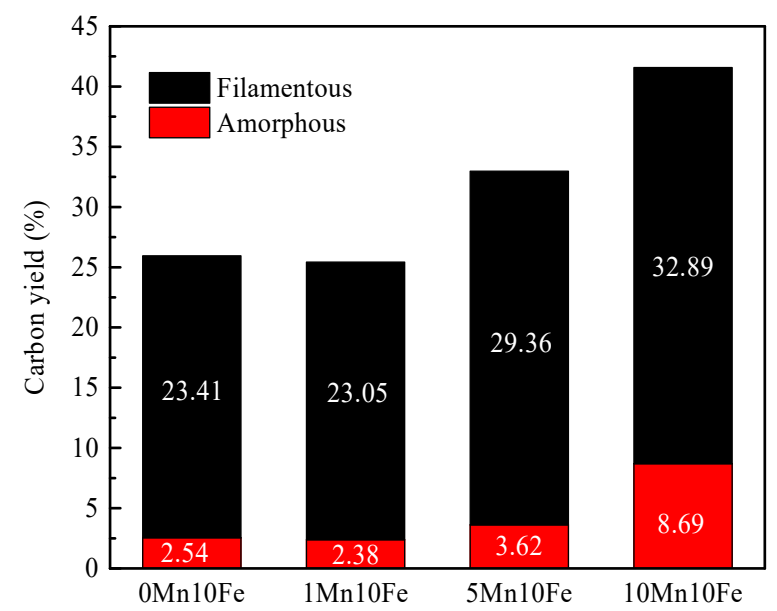

(a)

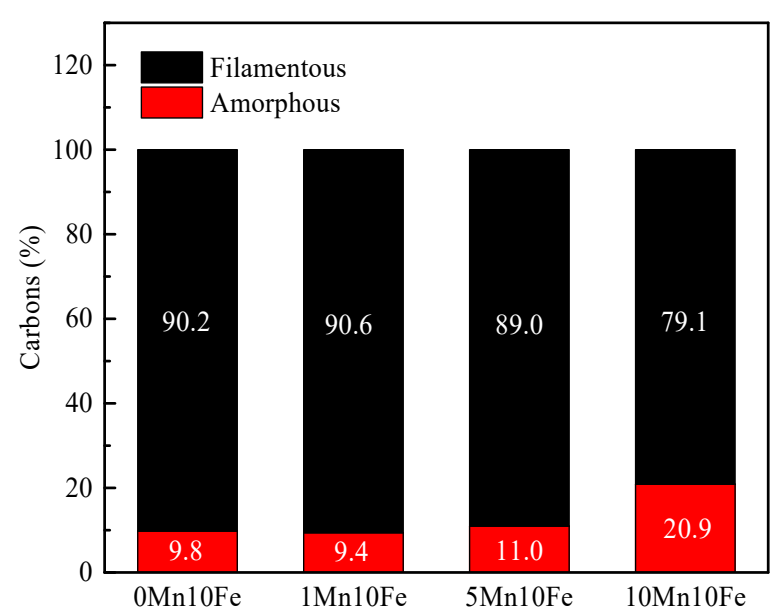

(b)

Fig. 5. (a) Amorphous/filamentous carbon yield on each of the reacted catalysts. (b) Mass ratio of amorphous and filamentous carbons on each catalyst.

\subsubsection{X-ray diffraction (XRD) of reacted catalysts}

Fig. 6 shows the XRD patterns of the four reacted catalysts. The Fe crystallite size is obtained from Scherrer equation. The results show that the Fe crystallite size of the four reacted catalysts is quite similar, which are $14.5 \mathrm{~nm}, 19.9 \mathrm{~nm}, 19.9 \mathrm{~nm}$, and $19.9 \mathrm{~nm}$ for the $0 \mathrm{Mn} 10 \mathrm{Fe}, 1 \mathrm{Mn} 10 \mathrm{Fe}$, $5 \mathrm{Mn} 10 \mathrm{Fe}$ and $10 \mathrm{Mn} 10 \mathrm{Fe}$ catalyst, respectively. From Fig. 6 , it can be seen that the four reacted catalysts mainly contain iron carbides $\left(\mathrm{Fe}_{3} \mathrm{C}\right.$ and $\left.\mathrm{Fe}_{5} \mathrm{C}_{2}\right)$ and $\mathrm{Fe}$ phases after reaction, suggesting that $\alpha-\mathrm{Fe}_{2} \mathrm{O}_{3}$ was fully reduced to $\mathrm{Fe}$ by the generated gas and then the reduced $\mathrm{Fe}$ was partically carbonised. Similar phase transformation of $\alpha-\mathrm{Fe}_{2} \mathrm{O}_{3}$ to $\mathrm{Fe}_{3} \mathrm{C}$ was also reported in the recent study (Zhang et al., 2020). For the $5 \mathrm{Mn} 10 \mathrm{Fe}$ and $10 \mathrm{Mn} 10 \mathrm{Fe}$ catalysts, there are additional peaks detected in the XRD patterns, indicating the existence of $\mathrm{MnO}$ phase. In addition, the peak intensity of $\mathrm{Fe}_{3} \mathrm{C}$ phase is decreased while the $\mathrm{Fe}_{5} \mathrm{C}_{2}$ intensity is increased with the increase of $\mathrm{Mn}$ content in the Fe-based catalyst. It is suggested that $\mathrm{Mn}$ in the catalyst promote the carburization of $\mathrm{Fe}_{5} \mathrm{C}_{2}$ rather than $\mathrm{Fe}_{3} \mathrm{C}$, hence, the carbon solubility per iron atom is reduced. Similary effects on hidering the carburization of $\mathrm{Fe}$ have also been reported (Lee et 


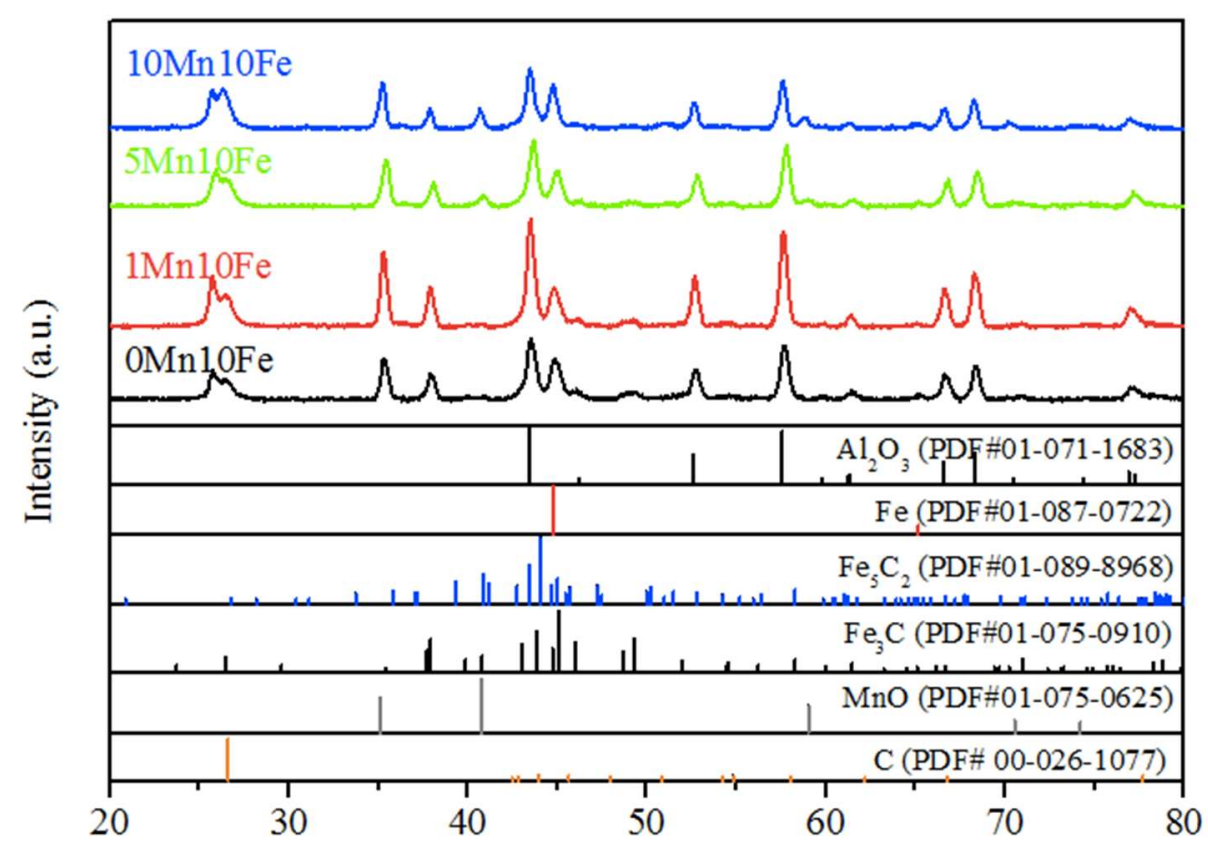

Degree $(2 \theta)$

Fig. 6. X-ray diffraction of the reacted Fe-based catalysts contain Mn.

\subsubsection{SEM and TEM results of the catalysts}

Fig. 7 shows the SEM results of the four fresh and reacted catalysts. It is indicated that the overall particle of the fresh catalyst is around $10 \mu \mathrm{m}$. After catalytic conversion of waste plastics, an aboundance of filamentous carbons could be clearly observed on the catalysts surface. The morphologies of the formed filamentous carbons on the four reacted catalysts were further investigated by TEM as shown in Fig. 8. The results illustrate the filamentous carbons with different structures in terms of size and homogenousness are formed over the four catalysts. Obviously, the metal particles are wrapped inside the tip of the CNTs, which is consistent with the tip growth mechanism of CNTs (Amelinckx et al., 1994). The formed CNTs with comparatively unsmooth and unhomogeneous structures are clearly observed for the $5 \mathrm{Mn} 10 \mathrm{Fe}$ and $10 \mathrm{Mn} 10 \mathrm{Fe}$ catalysts. The CNTs produced by the four catalysts have similar inner diameters (between 10-25 nm), which is consistent with the crystallite size of the active metal particles $(15-20 \mathrm{~nm})$ within the catalysts calculated from XRD results. It is demonstrated that the size of the CNTs is directly correlated to the particle size of active sites (Kotov et al., 2019)(Cheung et al., 2002; Ding et al., 2004; Nerushev et al., 2003). Interestingly, adding Mn to Fe-based catalysts seems to improve the radical growth of CNTs. As shown in Fig.8, the outer diameters of CNTs produced by the $0 \mathrm{Mn} 10 \mathrm{Fe}$ and $1 \mathrm{Mn} 10 \mathrm{Fe}$ catalysts are similar, ranging from $15-60 \mathrm{~nm}$, while the outer diameter of CNTs formed on $5 \mathrm{Mn} 10 \mathrm{Fe}$ and $10 \mathrm{Mn} 10 \mathrm{Fe}$ catalysts are larger (30$115 \mathrm{~nm}$ ). This may be attributed to the Mn contents affected the supersaturation degree of carbon atoms in the Fe nanoparticle as described in a recent study (Hayashi and Kohno, 2020). 

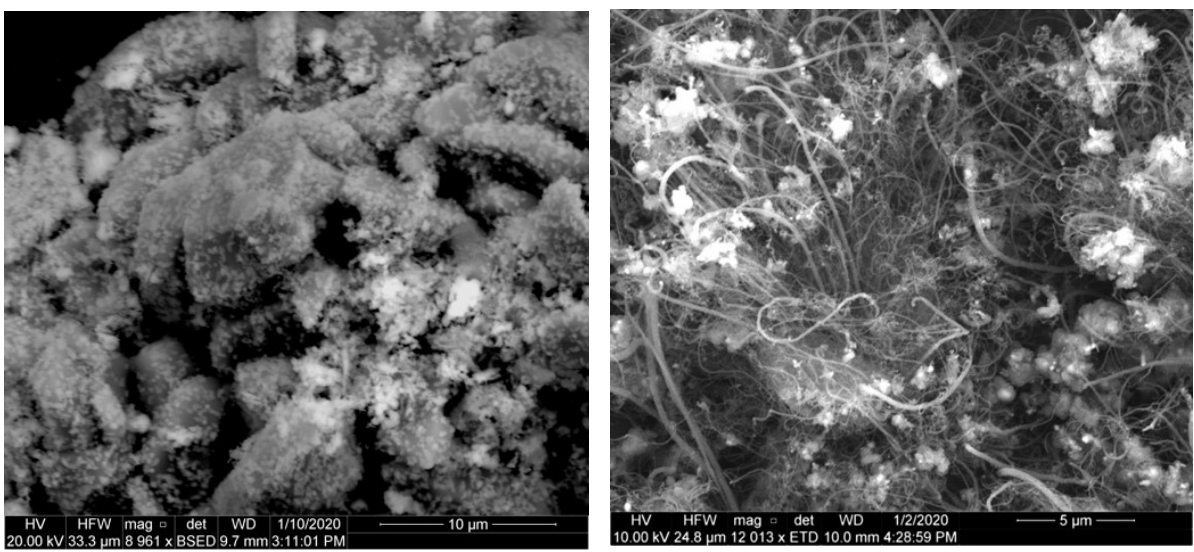

(a) $0 \mathrm{Mn} 10 \mathrm{Fe}$
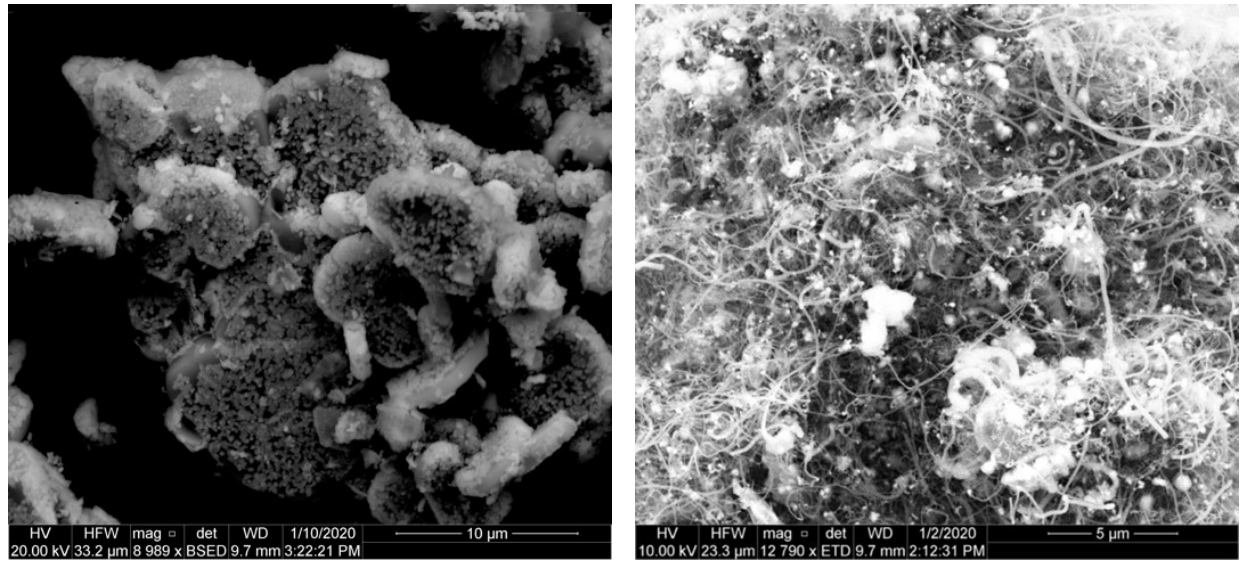

(b) $1 \mathrm{Mn} 10 \mathrm{Fe}$
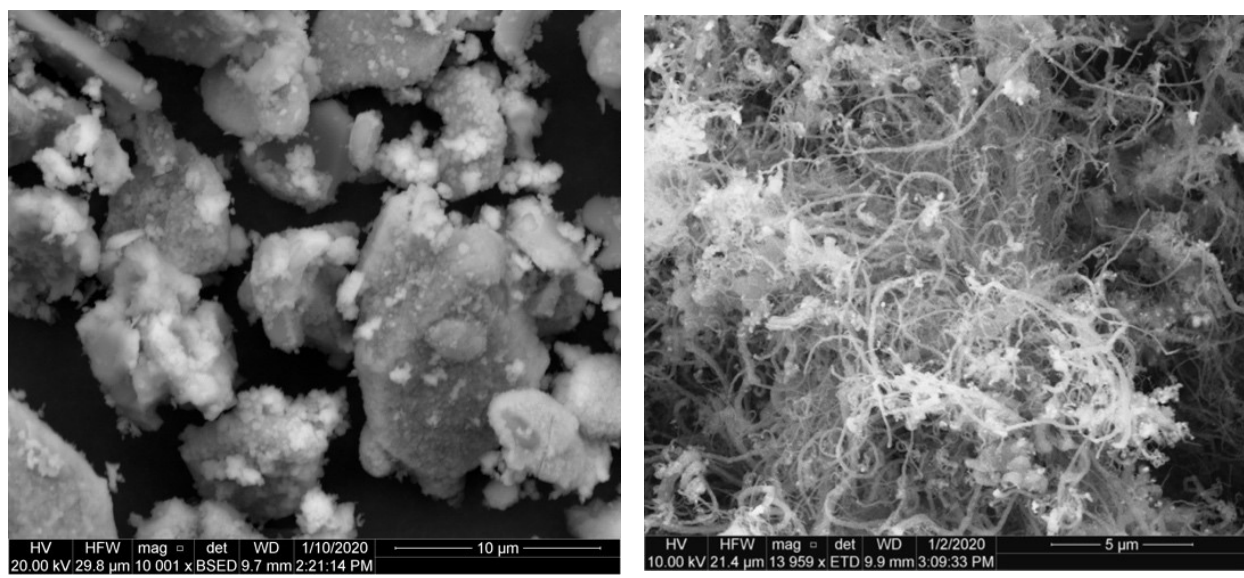

(c) $5 \mathrm{Mn} 10 \mathrm{Fe}$ 
333

334

335

336

337

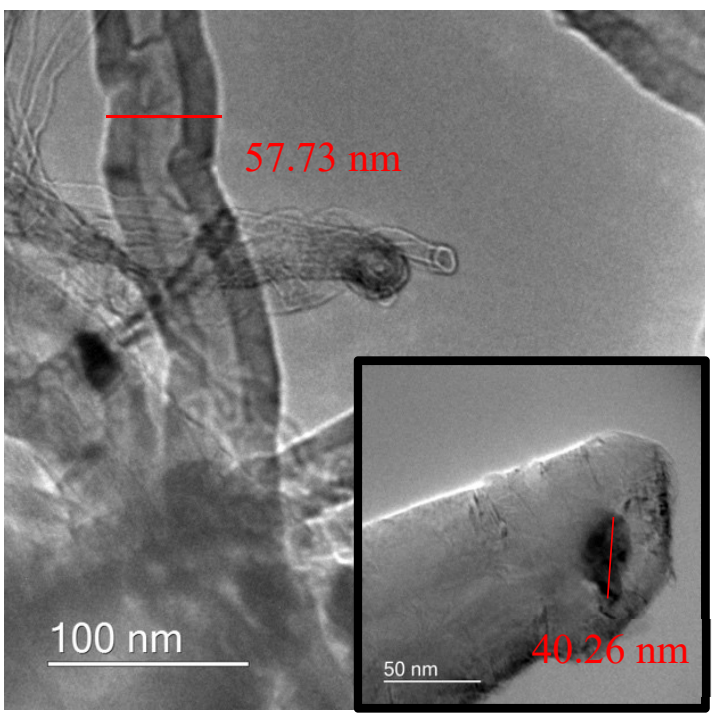

(a) $0 \mathrm{Mn} 10 \mathrm{Fe}$

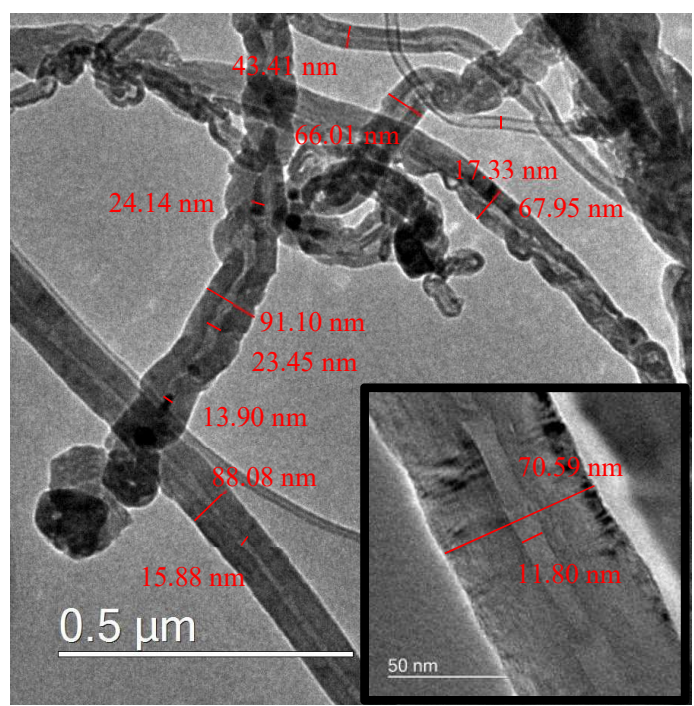

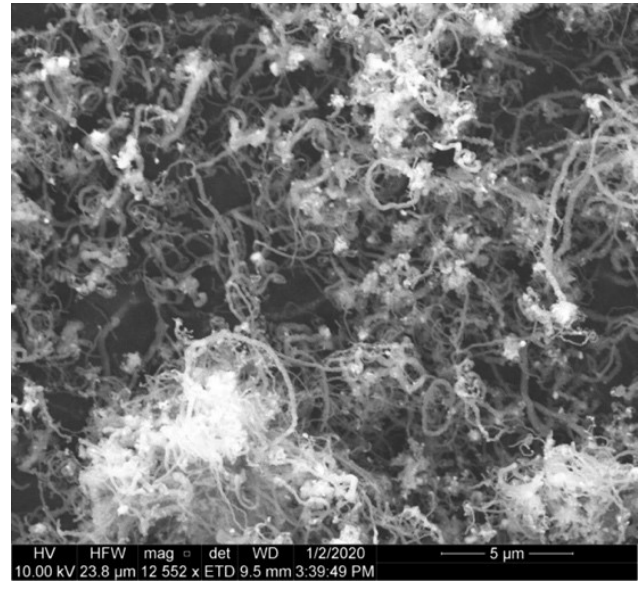

(d) $10 \mathrm{Mn} 10 \mathrm{Fe}$

Fig. 7. SEM morphology analysis of the fresh (left) and reacted (right) Mn containing Fe-based catalysts: (a) $0 \mathrm{Mn} 10 \mathrm{Fe}$ (b) $1 \mathrm{Mn} 10 \mathrm{Fe}$, (c) $5 \mathrm{Mn} 10 \mathrm{Fe}$ and (d) $10 \mathrm{Mn} 10 \mathrm{Fe}$.

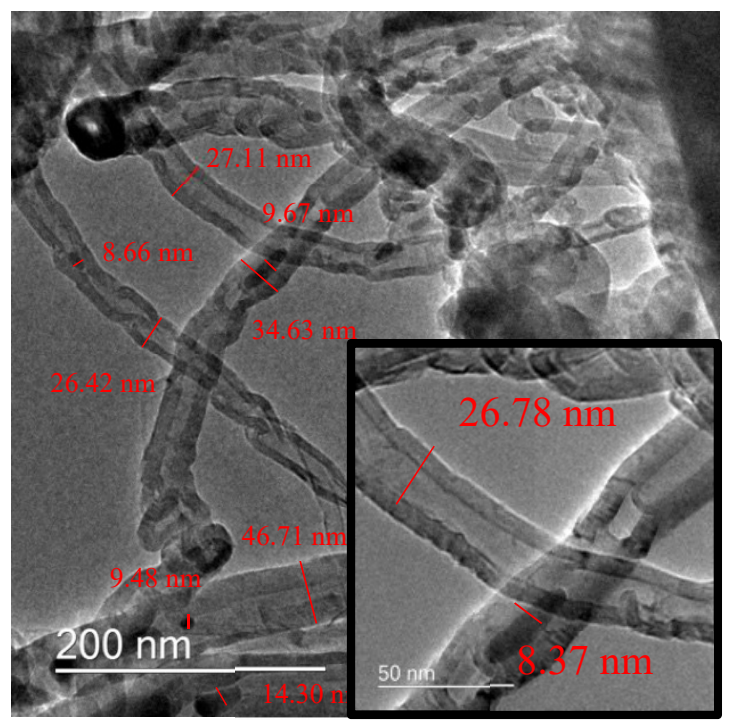

(b) $1 \mathrm{Mn} 10 \mathrm{Fe}$

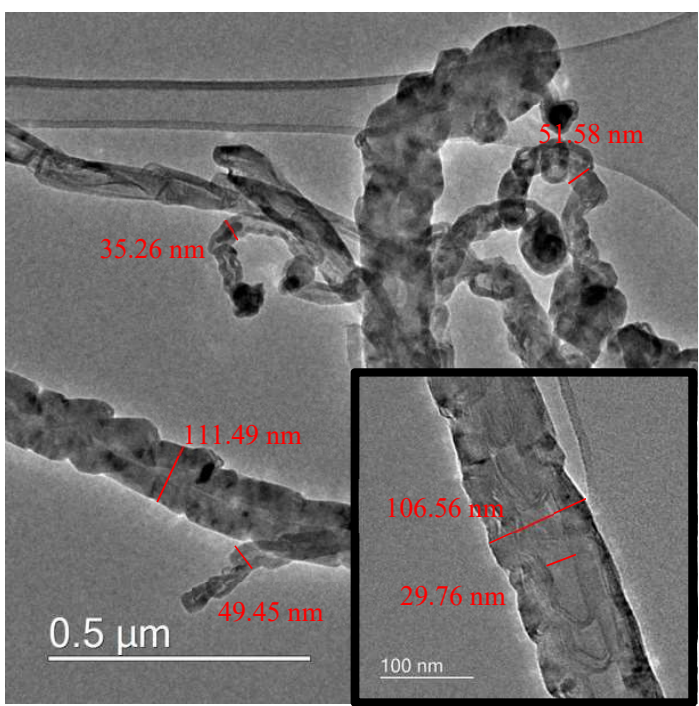


340 Fig. 8. TEM of the carbon deposition on the reacted Mn containing Fe-based catalysts: (a) $3410 \mathrm{Mn} 10 \mathrm{Fe}$ (b) $1 \mathrm{Mn} 10 \mathrm{Fe}$, (c) $5 \mathrm{Mn} 10 \mathrm{Fe}$ and (d) $10 \mathrm{Mn} 10 \mathrm{Fe}$.

\subsubsection{Raman spectra of the reacted catalysts}

343 Raman spectroscopy analysis was performed to characterise the structure of amorphous 344 and/or graphitic carbon and estimate the purity of CNTs (DiLeo et al., 2007; Ferrari and 345 Robertson, 2004). As shown in Fig.9, the Raman spectrum at wavelength of $1000-3000 \mathrm{~cm}^{-1}$ are presented to compare the carbons produced from the four Fe-based catalysts with varied Mn contents from 0-10wt.\%. The Raman spectra are dominated by three vibration bands characteristic of the Raman vibrations of carbonaceous materials: the D band at $\sim 1345 \mathrm{~cm}^{-1}$ arises from amorphous carbon or disordered carbon within structural defects; the $G$ band at $\sim 1573 \mathrm{~cm}^{-1}$ arises from the $\mathrm{sp}^{2}$ stretching vibration of the graphitic structures and is characteristic of graphitic samples; and the $\mathrm{G}^{\prime}$ band at $\sim 2680 \mathrm{~cm}^{-1}$ arises from the second-order scattering process of two phonons, indicating the purity of carbons (Dresselhaus et al., 2005; Saito et al., 2003). The $\mathrm{I}_{\mathrm{D}} / \mathrm{I}_{\mathrm{G}}$ ratio obtained by the normalizing the intensity of the $\mathrm{D}$ band to the $\mathrm{G}$ band could be used to evaluate the graphitization of carbons. As shown in Fig. 8, as the Mn content increases from $0 \mathrm{wt} . \%$ to $10 \mathrm{wt} . \%$, the carbon $\mathrm{I}_{\mathrm{D}} / \mathrm{I}_{\mathrm{G}}$ ratio decreases from 0.60 to 0.40 , suggesting that a higher amount of Mn doping could lead to a higher ratio of graphitic carbons. The $\mathrm{I}_{\mathrm{G}} / \mathrm{I}_{\mathrm{G}}$ ratio could be used to estimate the purity of CNTs (DiLeo et al., 2007). The $\mathrm{I}_{\mathrm{G}^{\prime}} / \mathrm{I}_{\mathrm{G}}$ ratios for $0 \mathrm{Mn} 10 \mathrm{Fe}, 1 \mathrm{Mn} 10 \mathrm{Fe}$ and $5 \mathrm{Mn} 10 \mathrm{Fe}$ are in a similar range, which indicates that the purity of the CNTs produced by the three catalysts is similar. The smallest $\mathrm{I}_{\mathrm{G}}, \mathrm{I}_{\mathrm{G}}$ ratios for the $10 \mathrm{Mn} 10 \mathrm{Fe}$ catalyst at 0.46 correspondes to the lowest purity of CNTs, which is aggreement with the TPO results shown in Fig. 5(b). Therefore, when the addition of Mn in the catalyst is below $10 \mathrm{wt} . \%$, the graphitization of the produced carbon could be improved. However when excessive Mn (10 wt.\%) is added into the iron-based catalyst, the purity of the produced carbon could be reduced.

Table 1 shows the comparison of our work with other different Fe-based catalyst in literatures. The detailed carbon yield, as well as the morphology and quality of produced CNTs are presented. It is indicated that $10 \mathrm{Mn} 10 \mathrm{Fe}$ produces a high yield of carbons in comparing with other works. In addition, a large portion of the generated gases were trapped in condensation system before passing through the second stage of reactor, which decreases the carbon feedstock for CNTs growth, thus, could decrease the $10 \mathrm{Mn} 10 \mathrm{Fe}$ catalyst capacity to produce the highest carbon yield. The excellent catalytic performance could be partially attributed to the addition of Mn. In addition, the CNTs grow on $10 \mathrm{Mn} 10 \mathrm{Fe}$ catalyst have the lowest $\mathrm{I}_{\mathrm{D}} / \mathrm{I}_{\mathrm{G}}$ ratio value, indicating that the produced CNTs are better graphitized than other catalysts. This could be also partially attributed to the promoting graphitization of $\mathrm{Mn}$ in the Fe-based catalysts. 


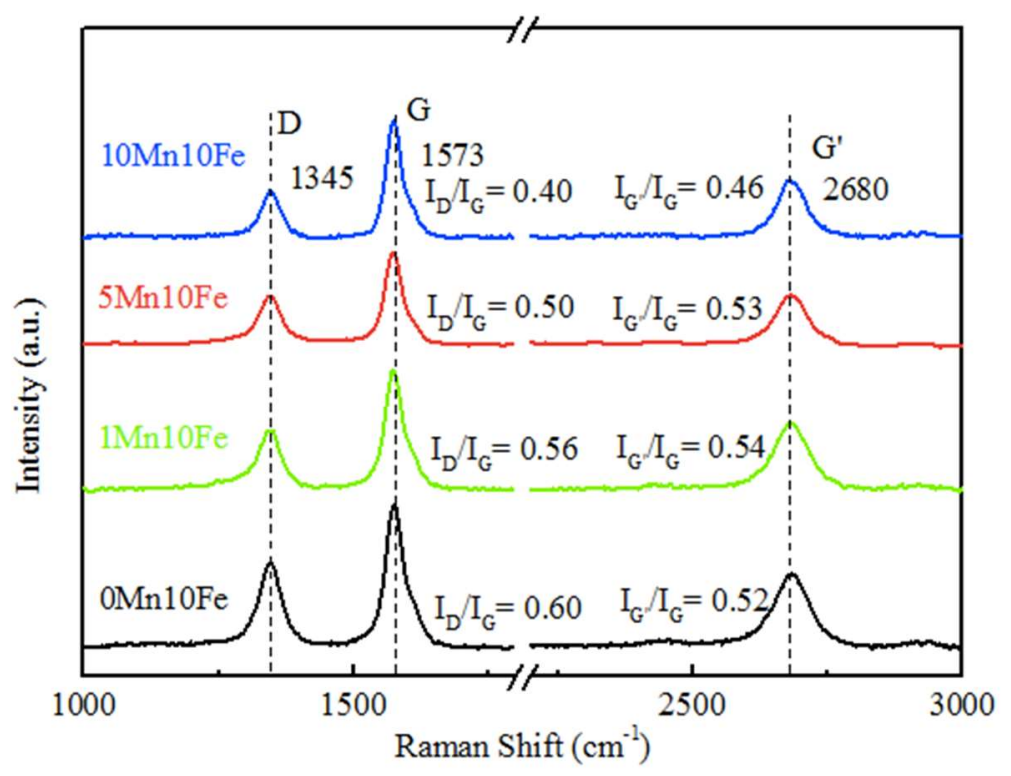

Fig. 9. Raman spectra of reacted catalysts.

Table 1

Comparison of carbon yield and Raman results between our research results and reports in literatures.

\begin{tabular}{|c|c|c|c|c|}
\hline Feedstock & Catalyst & $\begin{array}{l}\text { Carbon yield } \\
(\mathrm{wt} . \%)^{\mathrm{a}}\end{array}$ & $\mathrm{I}_{\mathrm{D}} / \mathrm{I}_{\mathrm{G}}$ & Ref. \\
\hline PP & $10 \mathrm{Mn} 10 \mathrm{Fe}$ & 41.5 & 0.4 & This work \\
\hline LDPE & $\mathrm{Fe} / \mathrm{Al}_{2} \mathrm{O}_{3}$ & 34.2 & 0.51 & $\begin{array}{l}\text { (Acomb et al., } \\
2016)\end{array}$ \\
\hline Waste tires & $\mathrm{Fe} / \mathrm{Al}_{2} \mathrm{O}_{3}$ & 21.9 & 0.89 & $\begin{array}{l}\text { (Zhang et al., } \\
2015 \text { ) }\end{array}$ \\
\hline PP & Fe/Cordierte & 3 & - & $\begin{array}{l}\text { (Wang et al., } \\
2019 \text { ) }\end{array}$ \\
\hline Realworld & $\mathrm{Fe} / \square-\mathrm{Al}_{2} \mathrm{O}_{3}$ & 41.3 & 0.64 & (Yao et al., 2018b) \\
\hline plastics & $\mathrm{Fe} / \square-\mathrm{Al}_{2} \mathrm{O}_{3}$ & 39.5 & 0.62 & \\
\hline \multirow[t]{2}{*}{ PP } & $\mathrm{Fe} / \mathrm{SiO}_{2}-\mathrm{S}$ & 39.4 & - & (Wu et al., 2017a) \\
\hline & $\mathrm{Fe} / \mathrm{SiO}_{2}-\mathrm{L}$ & 42.0 & - & \\
\hline
\end{tabular}

${ }^{a}$ Obtained from the recalculation of carbon yield reported from temperature programme oxidation analysis.

\section{Conclusion}

In this study, the addition of $\mathrm{Mn}$ into Fe-based catalysts with content at 0 wt.\%, 1wt.\%, 5 wt.\% and $10 \mathrm{wt} . \%$ have been investigated for catalytic pyrolysis of PP into CNTs. Mn is an effective promoter in the Fe-based catalyst for CNTs growth from catalytic pyrolysis of PP.

387 The enhanced metal-support interactions by Mn addition leads to a higher yield of carbons. The dispersion of iron nanoparticles is also enhanced by $\mathrm{Mn}$, inhibiting the sintering of iron particles. 
In addition, the iron oxide phase is stabilized by Mn addition, therefore contributing to the stability of catalytic Fe sites. Meanwhile, the catalyst with higher Mn content favours the formation of carbides at lower carbon concentration which promotes graphite precipitation from carbides intermediates. Owing to these effects, the yield and graphitization degree of the produced CNTs increases as Mn loading increases. However, the increased Mn loading in Febased catalyst has negative influence on the purity of produced CNTs. Although the $10 \mathrm{Mn} 10 \mathrm{Fe}$ catalyst produces the highest carbon yield (41.58 wt.\%) than other catalysts, the mass ratio of CNTs is much lower than the $5 \mathrm{Mn} 10 \mathrm{Fe}$ catalyst.

\section{Acknowledgment}

This project has received funding from the European Union's Horizon 2020 research and innovation programme under the Marie Skłodowska-Curie grant agreement No 823745.

\section{References}

Acomb, J.C., Wu, C., Williams, P.T., 2016. The use of different metal catalysts for the simultaneous production of carbon nanotubes and hydrogen from pyrolysis of plastic feedstocks. Appl. Catal. B Environ. 180, 497-510. https://doi.org/10.1016/j.apcatb.2015.06.054

Amelinckx, S., Zhang, X.B., Bernaerts, D., Zhang, X.F., Ivanov, V., Nagy, J.B., 1994. A Formation Mechanism for Catalytically Grown Helix-Shaped Graphite Nanotubes. Science (80-. ). 265, 635-639. https://doi.org/10.1126/science.265.5172.635

Andrews, R., Jacques, D., Qian, D., Rantell, T., 2002. Multiwall carbon nanotubes: Synthesis and application. Acc. Chem. Res. 35, 1008-17. https://doi.org/10.1021/ar010151m

Becker, M.J., Xia, W., Tessonnier, J.P., Blume, R., Yao, L., Schlögl, R., Muhler, M., 2011. Optimizing the synthesis of cobalt-based catalysts for the selective growth of multiwalled carbon nanotubes under industrially relevant conditions. Carbon N. Y. 49, 5253-5264. https://doi.org/10.1016/j.carbon.2011.07.043

Bezemer, G.L., Radstake, P.B., Falke, U., Oosterbeek, H., Kuipers, H.P.C.E., Van Dillen, A.J., De Jong, K.P., 2006. Investigation of promoter effects of manganese oxide on carbon nanofiber-supported cobalt catalysts for Fischer-Tropsch synthesis. J. Catal. 237, 152-161. https://doi.org/10.1016/j.jcat.2005.10.031

Bianco, A., Kostarelos, K., Prato, M., 2005. Applications of carbon nanotubes in drug delivery. Curr. Opin. Chem. Biol. 9, 674-679. https://doi.org/10.1016/j.cbpa.2005.10.005

Cheung, C.L., Kurtz, A., Park, H., Lieber, C.M., 2002. Diameter-controlled synthesis of carbon nanotubes. J. Phys. Chem. B 106, 2429-2433. https://doi.org/10.1021/jp0142278

Deck, C.P., Vecchio, K., 2006. Prediction of carbon nanotube growth success by the analysis 
of carbon-catalyst binary phase diagrams. Carbon N. Y. 44, 267-275. https://doi.org/10.1016/j.carbon.2005.07.023

DiLeo, R.A., Landi, B.J., Raffaelle, R.P., 2007. Purity assessment of multiwalled carbon nanotubes by Raman spectroscopy. J. Appl. Phys. 101. https://doi.org/10.1063/1.2712152

Ding, F., Rosén, A., Bolton, K., 2004. Molecular dynamics study of the catalyst particle size dependence on carbon nanotube growth. J. Chem. Phys. 121, 2775-2779. https://doi.org/10.1063/1.1770424

Ding, M., Qiu, M., Liu, J., Li, Y., Wang, T., Ma, L., Wu, C., 2013. Influence of manganese promoter on co-precipitated $\mathrm{Fe}-\mathrm{Cu}$ based catalysts for higher alcohols synthesis. Fuel 109, $21-$ 27. https://doi.org/10.1016/j.fuel.2012.06.034

Dresselhaus, M.S., Dresselhaus, G., Saito, R., Jorio, A., 2005. Raman spectroscopy of carbon nanotubes. Phys. Rep. 409, 47-99. https://doi.org/10.1016/j.physrep.2004.10.006

Drzyzga, O., Prieto, A., 2019. Plastic waste management, a matter for the 'community.' Microb. Biotechnol. 12, 66-68. https://doi.org/10.1111/1751-7915.13328

Ferrari, A.C., Robertson, J., 2004. Raman spectroscopy of amorphous, nanostructured, diamond-like carbon, and nanodiamond. Philos. Trans. R. Soc. A Math. Phys. Eng. Sci. 362, 2477-2512. https://doi.org/10.1098/rsta.2004.1452

Feyzi, M., Jafari, F., 2012. Study on iron-manganese catalysts for Fischer-Tropsch synthesis. Ranliao Huaxue Xuebao/Journal Fuel Chem. Technol. 40, 550-557. https://doi.org/10.1016/s1872-5813(12)60021-8

Hayashi, T., Kohno, H., 2020. Diameter-Modulated Multi-Walled Carbon Nanotubes Without Bamboo-Like Partitions: Growth, Structure and Deformation Behaviors. J. Nanosci. Nanotechnol. 20, 3038-3041. https://doi.org/https://doi.org/10.1166/jnn.2020.17451

He, M., Fedotov, P. V., Chernov, A., Obraztsova, E.D., Jiang, H., Wei, N., Cui, H., Sainio, J., Zhang, W., Jin, H., Karppinen, M., Kauppinen, E.I., Loiseau, A., 2016. Chiral-selective growth of single-walled carbon nanotubes on Fe-based catalysts using $\mathrm{CO}$ as carbon source. Carbon $\mathrm{N}$. Y. 108, 521-528. https://doi.org/10.1016/j.carbon.2016.07.048

Iijima, S., 1991. Helical microtubules of graphitic carbon. Nature 354, 56-58. https://doi.org/https://doi.org/10.1038/354056a0

Jia, J., Zhang, P., Chen, L., 2016. The effect of morphology of $\alpha-\mathrm{MnO} 2$ on catalytic decomposition of gaseous ozone. Catal. Sci. Technol. 6, 5841-5847. https://doi.org/10.1039/c6cy00301j

Karásková, K., Obalová, L., Jirátová, K., Kovanda, F., 2010. Effect of promoters in Co-Mn-Al mixed oxide catalyst on $\mathrm{N} 2 \mathrm{O}$ decomposition. Chem. Eng. J. 160, 480-487. https://doi.org/10.1016/j.cej.2010.03.058 
Lebreton, L., Andrady, A., 2019. Future scenarios of global plastic waste generation and disposal. Palgrave Commun. 5, 1-11. https://doi.org/10.1057/s41599-018-0212-7

Lee, M.D., Lee, J.F., Chang, C.S., Dong, T.Y., 1991. Effects of addition of chromium, manganese, or molybdenum to iron catalysts for carbon dioxide hydrogenation. Appl. Catal. 72, 267-281. https://doi.org/10.1016/0166-9834(91)85055-Z

Leith, I.R., Howden, M.G., 1988. Temperature-programmed reduction of mixed ironmanganese oxide catalysts in hydrogen and carbon monoxide. Appl. Catal. 37, 75-92. https://doi.org/10.1016/S0166-9834(00)80752-6

Lettieri, P., Al-Salem, S.M., 2011. Thermochemical Treatment of Plastic Solid Waste, Waste. Elsevier Inc. https://doi.org/10.1016/B978-0-12-381475-3.10017-8

Lin, J., Yang, Yihang, Zhang, H., Li, F., Yang, Yulin, 2020. Carbon nanotube growth on titanium boride powder by chemical vapor deposition: Influence of nickel catalyst and carbon precursor supply. Ceram. Int. 46, 12409-12415. https://doi.org/10.1016/j.ceramint.2020.02.002

Liu, Y., Qian, W., Zhang, Q., Ning, G., Luo, G., Wang, Y., Wang, D., Wei, F., 2009. Synthesis of high-quality, double-walled carbon nanotubes in a fluidized bed reactor. Chem. Eng. Technol. 32, 73-79. https://doi.org/10.1002/ceat.200800298

Modekwe, H.U., Mamo, M., Moothi, K., Daramola, M.O., 2020. Synthesis of bimetallic $\mathrm{NiMo} / \mathrm{MgO}$ catalyst for catalytic conversion of waste plastics (polypropylene) to carbon nanotubes (CNTs) via chemical vapour deposition method. Mater. Today Proc. https://doi.org/10.1016/j.matpr.2020.02.398

Nahil, M.A., Wu, C., Williams, P.T., 2015. Influence of metal addition to Ni-based catalysts for the co-production of carbon nanotubes and hydrogen from the thermal processing of waste polypropylene. Fuel Process. Technol. 130, 46-53. https://doi.org/10.1016/j.fuproc.2014.09.022

Nasser, A.H., Guo, L., Elnaggar, H., Wang, Y., Guo, X., Abdelmoneim, A., Tsubaki, N., 2018. $\mathrm{Mn}-\mathrm{Fe}$ nanoparticles on a reduced graphene oxide catalyst for enhanced olefin production from syngas in a slurry reactor. RSC Adv. 8, 14854-14863. https://doi.org/10.1039/c8ra02193g

Nerushev, O.A., Dittmar, S., Morjan, R.-E., Rohmund, F., Campbell, E.E.B., 2003. Particle size dependence and model for iron-catalyzed growth of carbon nanotubes by thermal chemical vapor deposition. J. Appl. Phys. 93, 4185-4190. https://doi.org/10.1063/1.1559433 
Pineau, A., Kanari, N., Gaballah, I., 2006. Kinetics of reduction of iron oxides by H2. Part I: Low temperature reduction of hematite. Thermochim. Acta 447, 89-100. https://doi.org/10.1016/j.tca.2005.10.004

Ran, M., Chu, W., Liu, Y., Liu, D., Zhang, C., Zheng, J., 2014. Doping effects of manganese on the catalytic performance and structure of $\mathrm{NiMgO}$ catalysts for controllabe synthesis of multi-walled carbon nanotubes. J. Energy Chem. 23, 781-788. https://doi.org/10.1016/S20954956(14)60212-6

Saito, R., Grüneis, A., Samsonidze, G.G., Brar, V.W., Dresselhaus, G., Dresselhaus, M.S., Jorio, A., Cançado, L.G., Fantini, C., Pimenta, M.A., Souza Filho, A.G., 2003. Double resonance Raman spectroscopy of single-wall carbon nanotubes. New J. Phys. 5. https://doi.org/10.1088/1367-2630/5/1/157

Shah, K.A., Tali, B.A., 2016. Synthesis of carbon nanotubes by catalytic chemical vapour deposition: A review on carbon sources, catalysts and substrates. Mater. Sci. Semicond. Process. 41, 67-82. https://doi.org/10.1016/j.mssp.2015.08.013

Sivakumar, V.M., Abdullah, A.Z., Mohamed, A.R., Chai, S.P., 2011. Optimized parameters for carbon nanotubes synthesis over Fe and Ni catalysts VIA methane CVD. Rev. Adv. Mater. Sci. $27,25-30$.

Tang, W., Wu, X., Li, D., Wang, Z., Liu, G., Liu, H., Chen, Y., 2014. Oxalate route for promoting activity of manganese oxide catalysts in total VOCs' oxidation: Effect of calcination temperature and preparation method. J. Mater. Chem. A 2, 2544-2554. https://doi.org/10.1039/c3ta13847j

Wang, J., Shen, B., Lan, M., Kang, D., Wu, C., 2019. Carbon nanotubes (CNTs) production from catalytic pyrolysis of waste plastics: The influence of catalyst and reaction pressure. Catal. Today 1-8. https://doi.org/10.1016/j.cattod.2019.01.058

Wu, C., Liu, X., Williams, P.T., Nahil, M.A., Zhang, Y., 2017a. Development of Ni- and Febased catalysts with different metal particle sizes for the production of carbon nanotubes and hydrogen from thermo-chemical conversion of waste plastics. J. Anal. Appl. Pyrolysis 125, 3239. https://doi.org/10.1016/j.jaap.2017.05.001

Wu, C., Nahil, M.A., Miskolczi, N., Huang, J., Williams, P.T., Engineering, P., Ls, L., $2017 b$. Production and application of carbon nanotubes, as a co-product of hydrogen from the pyrolysis-catalytic reforming of waste plastic. Process Saf. Environ. Prot. 103, 107-114. https://doi.org/10.1016/j.psep.2016.07.001

Wu, C., Williams, P.T., 2009. Hydrogen production from the pyrolysis-gasification of polypropylene: Influence of steam flow rate, carrier gas flow rate and gasification temperature. Energy and Fuels 23, 5055-5061. https://doi.org/10.1021/ef900278w

Xu, J.D., Zhu, K.T., Weng, X.F., Weng, W.Z., Huang, C.J., Wan, H.L., 2013a. Carbon nanotube-supported Fe-Mn nanoparticles: A model catalyst for direct conversion of syngas to 

nanotube-supported Fe-Mn nanoparticles: A model catalyst for direct conversion of syngas to lower olefins. Catal. Today 215, 86-94. https://doi.org/10.1016/j.cattod.2013.04.018 catalysts: Recent advances in synthesis, characterization and applications. Chem. Soc. Rev. 44, 3295-3346. https://doi.org/10.1039/c4cs00492b

Yang, R.X., Chuang, K.H., Wey, M.Y., 2015. Effects of Nickel Species on Ni/Al2O3 Catalysts in Carbon Nanotube and Hydrogen Production by Waste Plastic Gasification: Bench- and PilotScale Tests. Energy and Fuels 29, 8178-8187. https://doi.org/10.1021/acs.energyfuels.5b01866

Yang, Y., Xiang, H.W., Tian, L., Wang, H., Zhang, C.H., Tao, Z.C., Xu, Y.Y., Zhong, B., Li, Y.W., 2005. Structure and Fischer-Tropsch performance of iron-manganese catalyst incorporated with $\mathrm{SiO} 2 . \quad$ Appl. https://doi.org/10.1016/j.apcata.2005.01.025 precipitated iron-manganese catalyst for Fischer-Tropsch synthesis. Appl. Catal. A Gen. 266, 181-194. https://doi.org/10.1016/j.apcata.2004.02.018

Yao, D., Zhang, Y., Williams, P.T., Yang, H., Chen, H., 2018. Co-production of hydrogen and carbon nanotubes from real-world waste plastics: Influence of catalyst composition and operational parameters. Appl. Catal. B Environ. 221, 584-597. https://doi.org/10.1016/j.apcatb.2017.09.035

Zein, S.H.S., Mohamed, A.R., 2004. Mn/Ni/TiO2 catalyst for the production of hydrogen and carbon nanotubes from methane decomposition. Energy and Fuels 18, 1336-1345. https://doi.org/10.1021/ef0340864

Zghal, S., Jedidi, I., Cretin, M., Cerneaux, S., Abdelmouleh, M., 2020. One-step synthesis of highly porous carbon graphite/carbon nanotubes composite by in-situ growth of carbon nanotubes for the removal of humic acid and copper (II) from wastewater. Diam. Relat. Mater. 101, 107557. https://doi.org/10.1016/j.diamond.2019.107557

559 Zhang, T., Wang, Q., Lv, X., Luo, Y., Zhang, Y., 2020. Transformation of primary siderite 560 during coal catalytic pyrolysis and its effects on the growth of carbon nanotubes. Fuel Process. 561 Technol. 198, 106235. https://doi.org/10.1016/j.fuproc.2019.106235

562 Zhang, Y., Nahil, M.A., Wu, C., Williams, P.T., 2017. Pyrolysis-catalysis of waste plastic 563 using a nickel-stainless-steel mesh catalyst for high-value carbon products. Environ. Technol. 564 (United Kingdom) 38, 2889-2897. https://doi.org/10.1080/09593330.2017.1281351

565 Zhang, Y., Wu, C., Nahil, M.A., Williams, P., 2015. Pyrolysis-catalytic reforming/gasification 566 of waste tires for production of carbon nanotubes and hydrogen. Energy and Fuels 29, 3328- 
568 Zhao, A., Ying, W., Zhang, H., Hongfang, M., Fang, D., 2012. Ni/Al $2 \mathrm{O} 3$ catalysts for syngas 569 methanation: Effect of Mn promoter. J. Nat. Gas Chem. 21, 170-177. 570 https://doi.org/10.1016/S1003-9953(11)60350-2 